\title{
CONFIRMATION OF POLYGYRA CEREOLUS \\ (GASTROPODA: POLYGYRIDAE) IN PUERTO RICO, GREATER ANTILLES
}

\section{Confirmación de Polygyra cereolus (Gastropoda: Polygyridae) en Puerto Rico, Antillas Mayores}

\author{
Laurent Charles $^{1^{*}}$ and Arnaud Lenoble ${ }^{2}$
}

\begin{abstract}
${ }^{1}$ Muséum de Bordeaux-sciences et nature, 5 place Bardineau, 33000 Bordeaux, France. (D)orcid.org/0000-00016231-8127. ${ }^{2}$ PACEA-UMR CNRS 5199-Université de Bordeaux-Ministère de la Culture et de la Communication, Avenue Geoffroy St Hilaire, CS 50 023, 33615 Pessac cedex, France; (D) orcid.org/0000-0001-9023-9741. *For correspondence: 1.charles@mairie-bordeaux.fr.
\end{abstract}

\section{ABSTRACT}

Polygyra cereolus (Megerle von Mühlfeld, 1816) is a small air-breathing snail originating in Florida, which is considered as an invasive species and is reported from a wide area in the south of the United States to Mexico and in some in some Caribbean Islands, Hawaii, Spain and the Arabian peninsula. Here we report the observation of this species in Puerto Rico.

Keywords: land snail, new record, alien species, Greater Antilles.

\section{RESUMEN}

Polygyra cereolus (Megerle von Mühlfeld, 1816) es un pequeño caracol pulmonado originario de Florida, considerado una especie invasora, ahora ampliamente distribuido en el sur de los Estados Unidos a México y más localmente en el área del Caribe, Hawai, España y la Península Arábiga. Aquí presentamos la observación de esta especie en la isla de Puerto Rico.

Palabras clave: caracol, nuevo registro, especies foráneas, Antillas Mayores.

Polygyra cereolus (Megerle von Mühlfeld, 1816), commonly called the Southern Flatcoil, is a small pulmonate landsnail native to Florida (Pilsbry, 1940), in the family Polygyridae. This family originate from North America (Pilsbry, 1939). With 24 genera and about 294 species (Perez et al., 2014), it is a significant proportion of the North America land snail fauna. The genus Polygyra Say, 1818 comprises actually 5 (Perez et al., 2014) to 9 (MolluscaBase, 2019) valid species. It displays a depressed to planorboid shell, with striated whorls, a wide umbilicus and one parietal tooth. Maximum shell diameter is generally around $8 \mathrm{~mm}$, but can reach up to $18 \mathrm{~mm}$, while shell elevation is around $4 \mathrm{~mm}$.

Polygyra cereolus is the only species in the genus to have been reported as an invasive species, following accidental introductions in many countries. Its current distribution includes the southern United States (Perez, 2008) and Mexico (Thompson, 2008), as well as St Martin (Bertrand, 2002 as P. cf. plana; Neckheim \& Hovestadt, 2016) and Guadeloupe (Charles, 2014) in the Caribbean, Hawaii (Cowie, 1996), Spain (Navarro-Barrachina et al., 2012; Quiñonero-Salgado \& Soriano, 2015), Saudi Arabia (Neubert, 1995), the United Arab Emirates (Feulner et al., 2005), and Qatar (Al-Khayat, 2010).

In July 2013 one of us (AL) has been able to do some naturalistic observations, including a small land snail shell collection in the gardens of the University of Puerto Rico campus at Utuado $\left(18^{\circ} 15^{\prime} 25^{\prime \prime} \mathrm{N} ; 66^{\circ} 43^{\prime} 15^{\prime \prime} \mathrm{W}\right)$, in the centre of the island. Land snails have been 
looked for on the ground, among leaf litter resulting in the finding of fresh but empty shells. The specimens were sent to the Natural History Museum of Bordeaux where the shells were cleaned and observed with a binocular magnifying glass and then compared with West Indian material from the Museum's collection. The usual shell length and diameter measurements were made using a digital calliper. Photos of the specimen presented in this note have been made with a Pentax K5 digital camera and $90 \mathrm{~mm}$ macro lens. The shell is preserved as voucher at the Bordeaux Natural History Museum (catalog number: MHNBx 2018.19.1).

The status of new occurrence was established by consulting the lists of the island's terrestrial snail inventories (Van der Schalie, 1948; Aguayo, 1961, 1966; Grana Raffucci, 2007) as well as the naturalist databases documenting terrestrial molluscs in North America and the Caribbean (iNaturalist) or compiling the catalogues of natural history collections, including that of the University of Puerto Rico (iDigBio, GBIF).

The examination of the seven shells collected makes it possible to recognize two species. Six shells are identified as Bulimulus guadalupensis (Bruguière, 1789), a widespread species in the Caribbean region (e.g. Breure, 1974) and in Puerto Rico (Van der Schalie, 1948; Grana Raffucci, 2007) where it is reported since 19th century. The last specimen, the subject of this note, corresponds to a shell of Polygyra cereolus (Fig. 1).

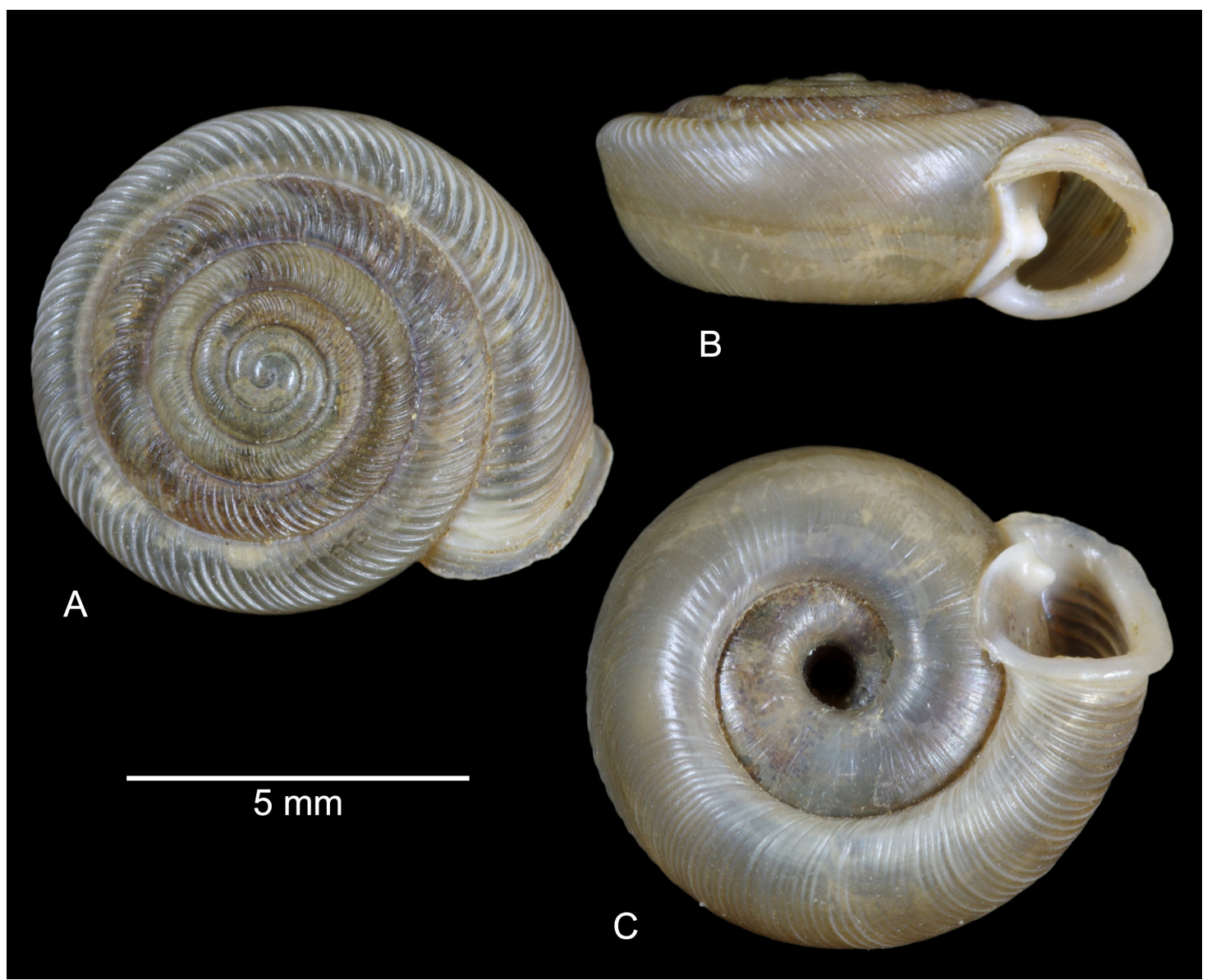

Figure 1. Specimen of Polygyra cereolus collected at the Utuado Campus, Puerto Rico. Apical view (A), apertural view (B), umbilical view (C). 
Polygyra cereolus is difficult to distinguish from P. septemvolva Say, 1818, and misidentification are probably frequent, as suggested by Perez et al. (2014). According to Pilsbry (1940), a well-developed parietal lamellae deep within the first half of the last whorl wall characterises $P$. cereolus. Our specimen fits well with the shell size, morphology and spire height variability from samples from Guadeloupe displaying the parietal lamellae (Charles, 2014).

From literature and natural history collections, Polygyra cereolus is not known in Puerto Rico. However, the species is listed and illustrated in a conference paper by Robinson and Fields (2014), but with no locality or habitat information. The occurrence that we report here thus confirms the presence of this species on the island while providing the first information on the context in which this snail can be observed in Puerto Rico.

With a land area of approximately $9,000 \mathrm{~km}^{2}$, Puerto Rico is a large island that harbours a rich and diverse terrestrial molluscan fauna with more than 180 species and subspecies (Grana Raffucci, 2007). This fauna was mainly inventoried and described during the 19th century (Shuttleworth, 1854; Crosse, 1892) and the first part of the 20th century (Dall \& Simpson, 1902; Van der Schalie, 1948). Knowledge have been enhanced by the contributions of Aguayo $(1961,1966)$ and more recently by the works of Grana Raffucci (2007). None of these publications lists Polygyra cereolus and the first report of this species in Puerto Rico appears to be the Robinson and Fields (2014) conference.

Our mention appears thus to be the second report of Polygyra cereolus on the island of Puerto Rico. It confirms the introduction of the species, around 2013 or a little earlier and provides a localized record that can help to trace the spread of this taxon on the island.

In its natural range, and in most localities where the species was introduced, P. cereolus lives in coastal environments, seemingly tolerating a certain salinity (Capinera \& White, 2011; Neckheim \& Hovestadt, 2016). It is also well acclimatised to gardens where irrigation provides favourable moisture conditions (Al-Khayat, 2010).

One of the main vectors for the spread and introduction of $P$. cereolus appears to be the trade and transport of living plants. In the Antilles, specimens were found in a shipment of potted plants (Miller, 1994), while its introduction on the Arabian Peninsula is assumed to have occurred along with turfgrass sod (Capinera \& White, 2011).

The Utuado campus is located in a rural environment in the centre of Puerto Rico. The snail was therefore not found in the coastal environment where it is frequently encountered when introduced. However, the introduction of this non-native snail may have accompanied the transport of plants to the university, the Utuado campus being specialized in agricultural technology studies.

This new record of Polygyra cereolus in Puerto Rico confirms its introduction into the island and shows that the dispersion of this species in the Caribbean is probably more important than the few known reports indicate. In addition, the taxon has been observed in a garden context which may be conducive to the establishment of a population, especially if new individuals are likely to be introduced through the importation of new plants. 


\section{ACKNOWLEDGMENTS}

The authors are grateful to Natasha Reynolds who kindly reviewed the English language of this note and to the anonymous reviewers for their comments that improved the first version of the manuscript.

\section{LITERATURE CITED}

Aguayo, C. G. 1961. Aspecto general de la fauna malacologica puertoriqueña. Caribbean Journal of Sciences, 1: 89-105.

Aguayo, C. G. 1966. Una lista de los moluscos terrestres y fluviales de Puerto Rico. Stahlia, 5: $1-17$.

A1-Khayat, J. 2010. First record of five terrestrial snails in the State of Qatar. Turkish Journal of Zoology, 34: 539-545.

Bertrand, A. 2002. Notes sur les mollusques terrestres de Saint-Martin (Petites Antilles). Documents Malacologiques, 3: 35-37.

Breure, A. S. H. 1974. Caribbean land molluscs: Bulimulidae I. Bulimulus. Studies on the Fauna of Curaçao and other Caribbean Islands, 145: 2-80.

Capinera, J. L., \& J. White. 2011. Terrestrial snails affecting plants in Florida. Entomology and Nematology Department, Florida Cooperative Extension Service, Institute of Food and Agricultural Sciences, University of Florida, $12 \mathrm{pp}$.

Charles, L. 2014. Signalement de Polygyra cereolus (Megerle von Mühlfeld, 1816) (Mollusca: Gastropoda: Pulmonata: Polygyridae) à la Guadeloupe (Petites-Antilles). MalaCo, 10: 5-6.

Cowie, R. H. 1996. New records of introduced land and freshwater snails in the Hawaiian Islands. Records of the Hawaii Biological Survey for 1995, part 2, 46: 25-27.

Crosse, H. 1892. Faune malacologique terrestre et fluviatile de l'île de Portorico. Journal de Conchyliologie, 40: 5-71.

Dall, W. H., \& C. T. Simpson. 1902. The mollusca of Porto Rico. Bulletin of the United States Fish Commission, 20: 353-524.

Feulner, G., E. Neubert, \& S. A. Green. 2005. Land snails, pp. 222-226. In: P. Hellyer and S. Aspinall (Eds.), The Emirates. A natural history. Trident Press Limited: 222-226.

Grana Raffucci, F. A. 2007. Nomenclatura de los organismos acuáticos y marinos de Puerto Rico e Islas Virgenes Vol. 6. Moluscos de Puerto Rico e islas vírgenes. Parte 5. Clase Gastropoda, Orden Pulmonata. Departamento de Recursos Naturales y Ambientales, 35 pp. http://www. drna.pr.gov/documentos/vol-6-nomenclatura-de-los-organismos-acuaticos-y-marinos-depr-e-islas-virgenes-8/.

Miller, S. E. 1994. Dispersal of plant pests into the Virgin Islands. Florida Entomologist, 77 (4): $520-521$. 
MolluscaBase (2019). MolluscaBase. Polygyra Say, 1818. Available at: http://molluscabase.org/ aphia.php? $\mathrm{p}=$ taxdetails\&id=996662 (accessed on: 2020-07-05).

Navarro-Barrachina, S., A. López Alabau, A. Pérez Ferrer, R. Ruiz Jarillo, \& S. Quiñonero-Salgado. 2012. Sobre la presencia de Polygyra cereolus (Mühlfeld, 1816) (Gastropoda: Polygyridae) en España. Spira, 4: 169-170.

Neckheim, C. M., \& A. Hovestadt. 2016. Land- en zoetwatermollusken verzameld op Sint Maarten (Nederlandse Antillen) en Saint Martin. Spirula, 409: 18-24.

Neubert, E. 1995. Two species of land snails in Saudi Arabia. Malacological Review, 28: $125-126$.

Perez, K. E. 2008. Polygyridae (43-48). In: Perez, K. E., \& R. J. Cordeiro (Eds.). A guide for terrestrial gastropods identification. American Malacological Society, Carbondale, Illinois.

Perez, K. E., N. Defreitas, J. Slapcinsky, R. L. Minton, F. E. Anderson, \& T. A. Pearce. 2014. Molecular phylogeny, evolution of shell shape, and DNA barcoding in Polygyridae (Gastropoda: Pulmonata), an endemic North American clade of land snails. American Malacological Bulletin, 32 (1): 1-31.

Pilsbry, H. A. 1939. Land Mollusca of North America (North of Mexico). The Academy of Natural Sciences of Philadelphia, Monograph 3, vol. 1 (1): 1-573.

Pilsbry, H. A. 1940. Land Mollusca of North American (North of Mexico). The Academy of Natural Sciences, Philadelphia, Monograph 3, vol. 1 (2): 575-994.

Quiñonero-Salgado, S., \& J. L. Soriano. 2015. Nuevas citas de Polygyra cereolus (Mühlfeld, 1816) (Gastropoda: Polygyridae) en Cataluña. Spira, 5: 199-200. MolluscaBase 2019. MolluscaBase. Polygyra Say, 1818. Available at: http://molluscabase.org/aphia.php?p=taxdetailsandid=996662 (accesed: 2020-05-18).

Robinson, D.W., \& A. Fields. 2014. Preliminary report on the terrestrial malacofauna of Puerto Rico and associated islands. Mollusca 2014, Mexico City, 22-27 June. (Conference paper).

Shuttleworth, R. J. 1854. Beiträge zur näheren Kenntniss der Land- und SüsswasserMollusken der Insel Portorico. Mittheillungen der naturforschenden Gesellschaft, Bern, 314-316: 33-56.

Thompson, F. G. 2008. An Annotated Checklist and Bibliography of the Land and Freshwater Snails of Mexico and Central America, 903 pp. Available at: http:/www.flmnh.ufl.edu/ malacology/mexico-central_america_snail_checklist/ (accesed: 16 June 2008).

Van der Schalie, H. 1948. The land and fresh-water mollusks of Puerto Rico. Miscellaneous Publication, University of Michigan, Museum of zoology, 70: 1-134.

[Recibido: 17 de diciembre, 2019. Aceptado para publicación: 20 de mayo, 2020] 